\title{
DURA MATER MITRAL AND TRICUSPID BIOPROSTHESES: 30 YEARS OF FOLLOW-UP
}

\author{
Luiz Boro Puig, Carlos Manuel de Almeida Brandão, Lauro Kawabe, Geraldo \\ Verginelli, José Antonio Francchini Ramires and Sérgio Almeida de Oliveira
}

PUIG LB et al. - Dura mater mitral and tricuspid bioprostheses: 30 years of follow-up. Rev. Hosp. Clín. Fac. Med. S. Paulo 58(3):163-168, 2003.

PURPOSE: The dura mater bioprosthesis was developed in the Department of Cardiopneumology of the Hospital das Clínicas of the University of São Paulo Medical School in 1971. Here, we present the clinical results of the dura mater bioprosthesis over 30 years of follow-up.

METHODS: We studied 70 consecutive patients who underwent mitral or tricuspid valve replacement with a dura mater bioprosthesis between January 1971 and August 1972.

RESULTS: The early mortality was $10 \%$ (7 patients). The follow-up was $87 \%$ complete ( 9 patients were lost to followup). Two patients were alive and asymptomatic 30 years after valve replacement; 33 patients underwent reoperations due to valve dysfunction, and 19 died during the follow-up period. At 30 years, the actuarial survival was $49.2 \pm 8.6 \%$; freedom from rupture, $27.0 \pm 10.2 \%$; freedom from calcification, $78.8 \pm 8.6 \%$; and freedom from reoperation, $18.8 \pm 7.5 \%$.

CONCLUSIONS: The dura mater bioprosthesis played an important role in the treatment of patients with mitral and tricuspid valve disease. The low rate of thromboembolism and the long period of follow-up without evidence of valve dysfunction, which occurred for several of our patients, are important characteristics of these bioprosthesis.

DESCRIPTORS: Dura mater. Bioprosthesis. Glycerol. Valve disease. Valve surgery.

The dura mater bioprosthesis was an original contribution developed in 1971 in the Department of Cardiopneumology of the Hospital das Clínicas, University of São Paulo Medical School ${ }^{1,2}$. In the 1960s, the Starr-Edwards ball-valve prosthesis was the only valve substitute available. This prosthesis was associated with a high incidence of thromboembolic events, mainly involving mitral valve replacement, with a prevalence of cerebrovascular accidents over 4 years of evolution of $27.4 \%$. The homologous dura mater bioprosthesis was developed for the purpose of preventing this serious complication. The initial and midterm results with this bioprosthesis were satisfactory. After 6 years of follow-up, some patients pre- sented with fatigue injuries, manifested as tears in the dura mater cusps. Despite this complication, the low rate of thromboembolism indicated the use of this prosthesis instead of the StarrEdwards prosthesis.

In the early 1980s, the use of the dura mater bioprosthesis was discontinued. The heterologous porcine and pericardial bioprosthesis, prepared with glutaraldehyde, became the first choice for use in heart valve replacement due to the higher availability, su-

From the Department of Cardiopneumology of the Heart Institute, Hospital das Clínicas, Faculty of Medicine, University of São Paulo.

Received for publication on October 07, 2002. perior quality control, and lower rates of associated structural valve deterioration observed during short-term follow-up.

In this paper, we present the clinical evolution of the first series of 70 patients with dura mater bioprosthesis in the mitral and tricuspid positions, 30 years after the operation.

\section{PATIENTS AND METHODS}

Seventy consecutive patients underwent mitral (68 patients) or tricuspid (2 patients) valve replacement with a dura mater bioprosthesis from January 1971 to August 1972 (Fig. 1). The clinical follow-up was concluded in August 2002. 


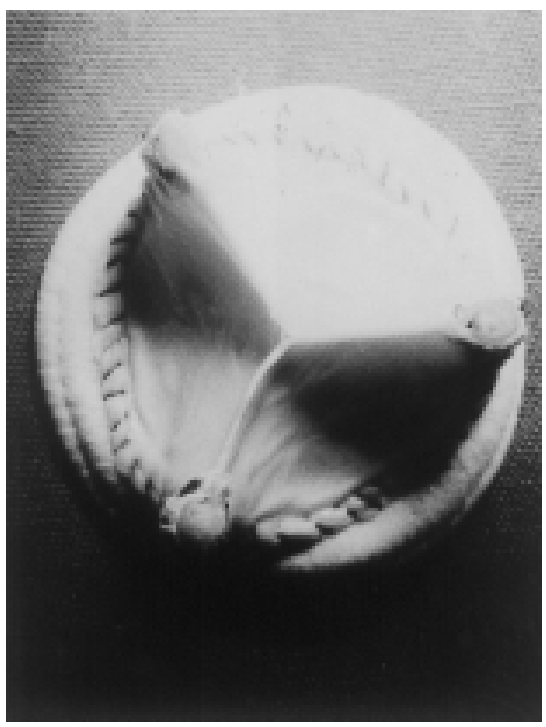

Figure 1- Model of implanted dura mater bioprosthesis.

Forty-two patients $(60 \%)$ were female and $28(40 \%)$ were male. The age of the patients ranged from 17 to 54 years. The valve lesions identified preoperatively were as follows: mitral insufficiency in 26 patients (37.1\%), double mitral lesions in 20 (28.6\%), mitral stenosis in $3(4.3 \%)$, tricuspid insufficiency in $1(1.4 \%)$, thromboembolism due to a Starr-Edwards mitral prostheses in $18(25.7 \%)$, infective endocarditis in $1(1.4 \%)$, and Ebstein's disease in $1(1.4 \%)$.

Clinical information was obtained from the patients through clinical examination, letter, or telephone contact, or from clinical cardiologists' reports. The follow-up was completed on $87 \%$ of patients ( 9 patients were lost to follow-up) completed over a closing period of 6 months, with a cumulative follow-up period of 555 years and an average follow-up interval of 10.3 years.

Definitions of complications, as well as data analysis and reporting of results, are in accordance with recommended guidelines ${ }^{4}$.

\section{RESULTS}

Hospital mortality was $10 \%$ (7 patients), which was attributable to heart failure in 5 patients $(71.4 \%)$, a stroke in 1 patient (14.3\%), and bronchopneumonia in 1 patient (14.3\%). Five of the 7 patients presented preoperatively

Table 1 - Causes of Late Mortality.

\begin{tabular}{lll}
\hline Cause of mortality & Patients & $\%$ \\
\hline Heart failure & 7 & 36.8 \\
Cerebrovascular accident & 2 & 10.5 \\
Arrhythmia & 2 & 10.5 \\
Bronchopneumonia & 2 & 10.5 \\
Endocarditis & 2 & 10.5 \\
Acute abdominal disease & 1 & 5.3 \\
Mesenteric thrombosis & 1 & 5.3 \\
Unknown & 2 & 10.5 \\
\hline TOTAL & $\mathbf{1 9}$ & $\mathbf{1 0 0}$ \\
\hline
\end{tabular}

Table 2 - Reoperation: causes, time of event, and follow-up period of events.

\begin{tabular}{llllll}
\hline Cause & No. of cases & Time of event & \multicolumn{3}{l}{ Follow- up period of event } \\
& (years) & $0-10 \mathrm{y}$ & $11-20 \mathrm{y}$ & $21-30 \mathrm{y}$ \\
\hline Rupture & $23(70 \%)$ & $\begin{array}{l}3-28 \\
(\text { mean }=15)\end{array}$ & $9(40 \%)$ & $7(30 \%)$ & $7(30 \%)$ \\
Calcification & $5(15 \%)$ & $\begin{array}{l}8-17 \\
(\text { mean }=12.4)\end{array}$ & $1(20 \%)$ & $4(80 \%)$ \\
Technical failure & $3(9 \%)$ & $\begin{array}{l}1-3 \\
(\text { mean }=2)\end{array}$ & $3(100 \%)$ \\
Paravalvar leak & $1(3 \%)$ & $\begin{array}{l}\text { Immediate } \\
8\end{array}$ & $1(100 \%)$ \\
Hemolysis & $1(3 \%)$ & $8(100 \%)$ & \\
\hline TOTAL & $33(100 \%)$ & &
\end{tabular}

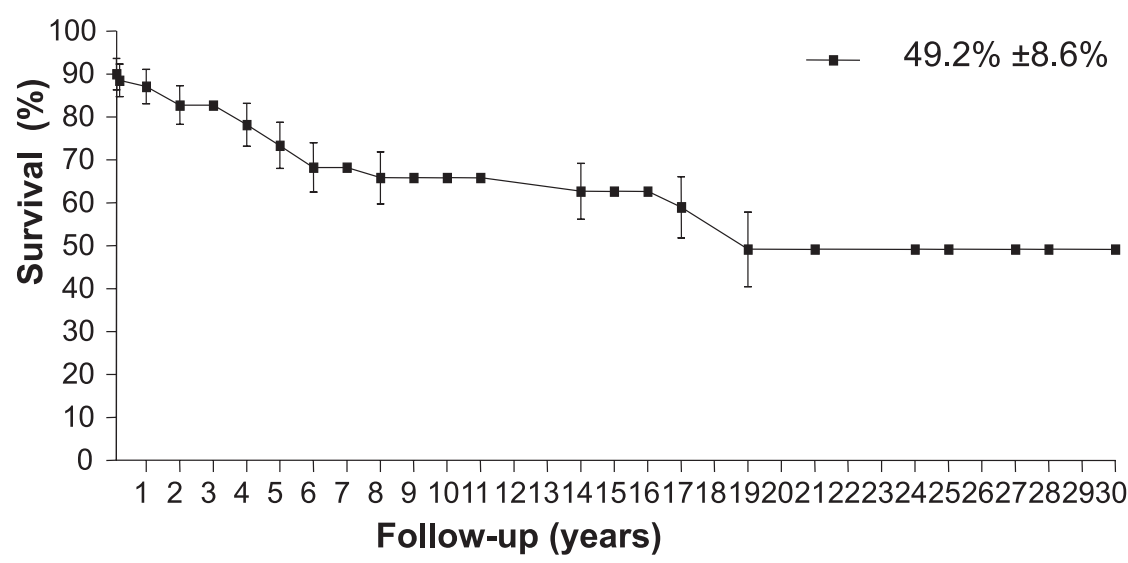

Figure 2 - Actuarial survival. with neurologic deficits caused by Starr-Edwards valve thrombosis and underwent emergency operations in a state of hemodynamic instability.

Nineteen died during the late follow-up period from a variety of causes (Table 1). Late mortality was considered as valve-related in 5 patients; 2 patients had prosthetic valve endocarditis, 2 patients had a stroke, and 1 patient had mesenteric thrombosis. Thirty-three patients underwent reoperations during the follow-up period due to valve dysfunction (Table 2).

During the late follow-up period, 9 patients were lost to follow-up, and 2 were alive 30 years after the surgery. In our patient population, the actuarial survival was $49.2 \% \pm 8.6 \%$ (Fig. 2); freedom from rupture, $27.0 \% \pm 10.2 \%$ (Fig. 3); freedom from calcification,

\section{Follow-up (years)}




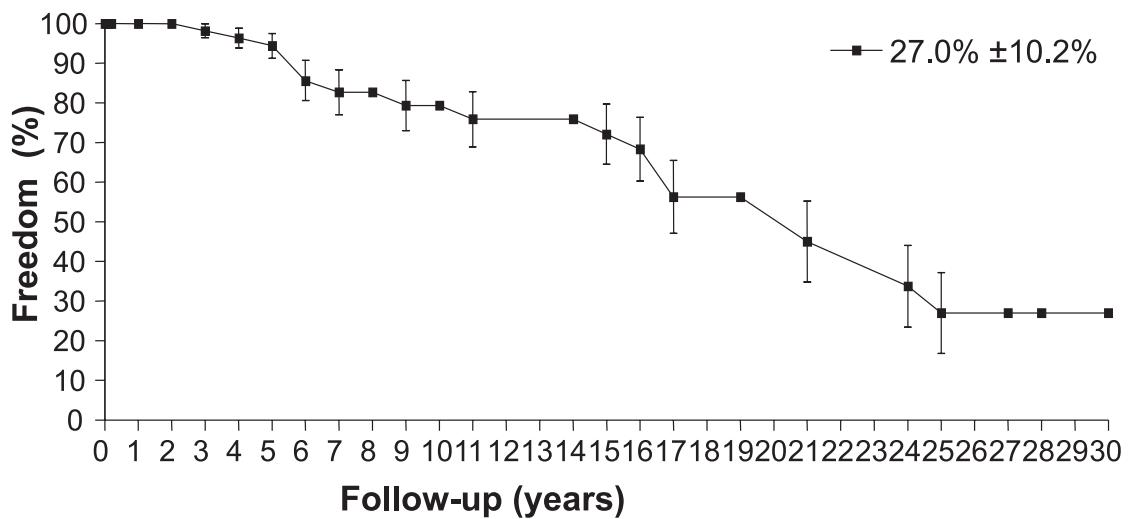

Figure 3 - Actuarial freedom from rupture.

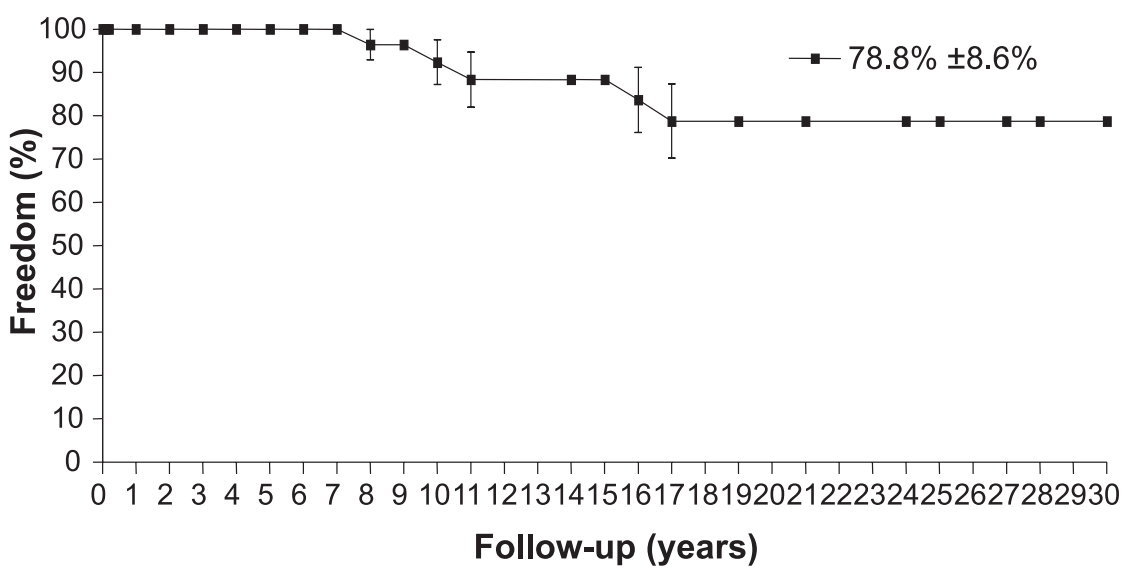

Figure 4 - Actuarial freedom from calcification.

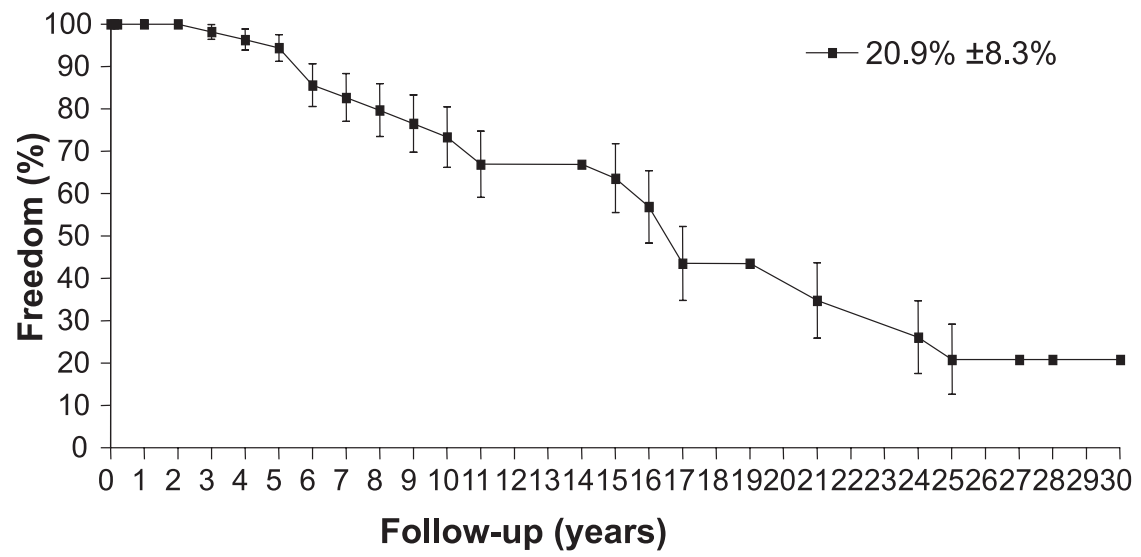

Figure 5 - Actuarial freedom from structural valve dysfunction.

$78.8 \% \pm 8.6 \%$ (Fig. 4); freedom from structural valve deterioration, $20.9 \%$ $\pm 8.3 \%$ (Fig. 5); freedom from reoperation, $18.8 \% \pm 7.5 \%$ (Fig. 6 ); and freedom from thromboembolism, $91.4 \% \pm 4.3 \%$ (Fig. 7).

\section{DISCUSSION}

The thromboembolic events associated with Starr-Edwards prostheses represent one of the most serious complications related to mechanical pros- theses. In mitral valve replacement, the rate of thromboembolism is high, and several patients have experienced permanent neurologic sequelae. The new mechanical prostheses offer low rates of thromboembolism, although patients are kept under anticoagulant therapy and are subjected to its risks. New materials and structural modifications of mechanical and biological prostheses have been evaluated in several clinical and experimental studies to identify means of reducing the risk of thromboembolic events.

Following experimental studies on homologous dura mater preserved in glycerol by Pigossi et al. ${ }^{5}$, this biological tissue was used as an implant by several surgical groups in the early 1970s. After experimental study, we observed that homologous dura mater was an appropriate tissue for making bioprosthetic cusps for heart valve replacement during cardiac surgery. The structure of dura mater, consisting of 2 layers of collagen fibers disposed in many directions, confers great resistance and pliability, which are both essential to valve function.

The initial clinical results with dura mater bioprostheses were very favorable, and this prosthesis soon became our first choice for use in heart valve replacement. The presentation of our results stimulated a great number of surgeons and institutions to use or study this bioprosthesis ${ }^{6-12}$. Harasaki et al. ${ }^{13}$, comparing aortic bovine valves treated with glutaraldehyde and human dura mater bioprostheses treated with glycerol, showed that dura mater bioprostheses were more durable.

The main objection to the use of dura mater bioprostheses relates to the use of glycerol for their preparation. That is, there is concern that glycerol is not an efficient sterilizing agent, although none of our patients experienced early infective endocarditis. The cases of infective endocarditis observed in our series all occurred dur- 


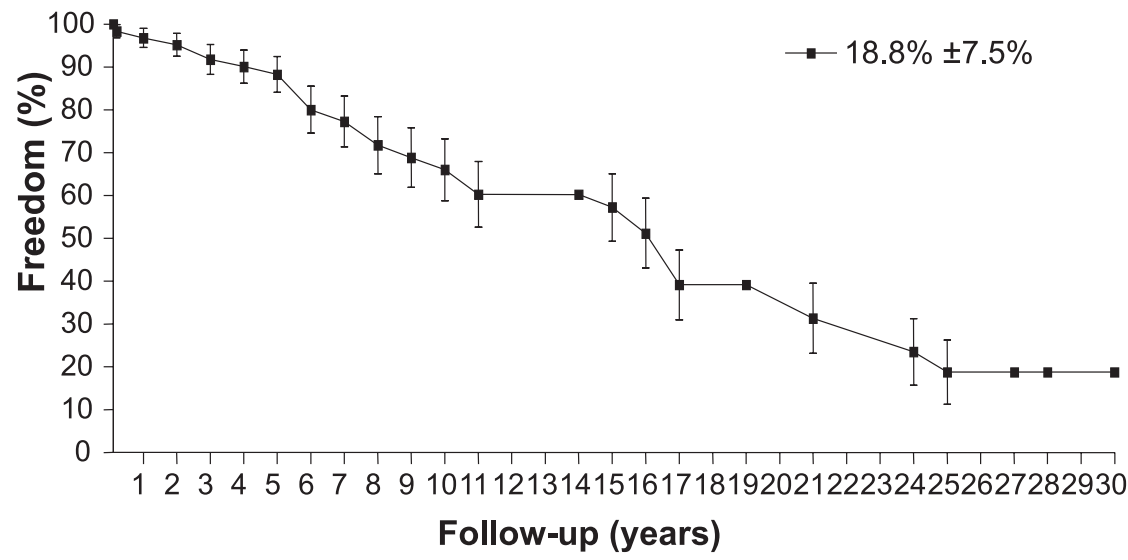

Figure 6 - Actuarial freedom from reoperation.

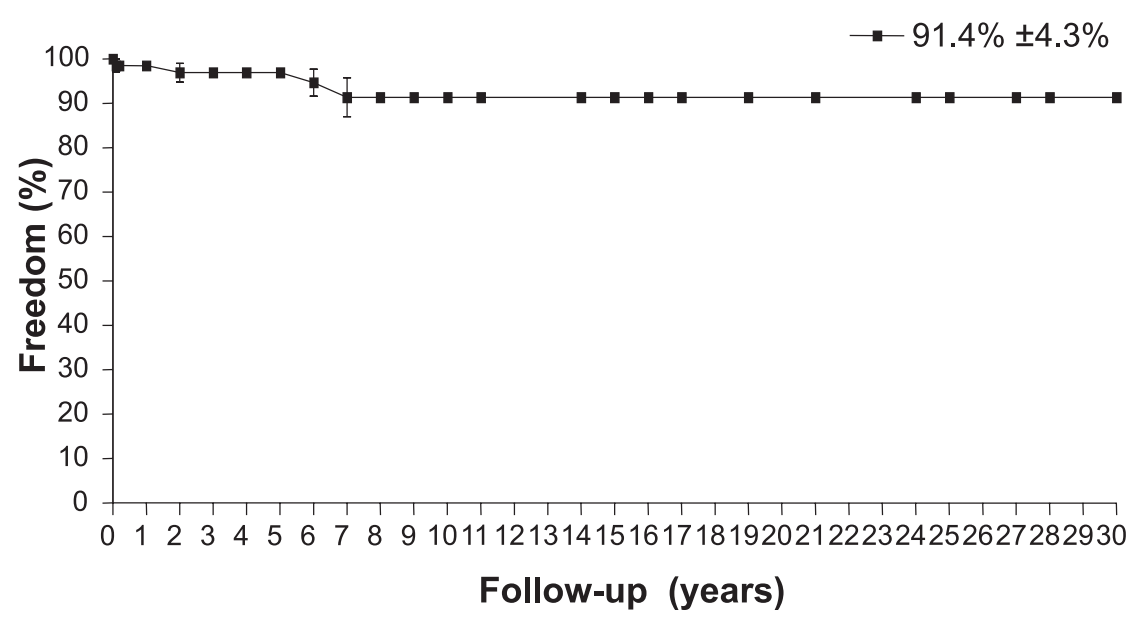

Figure 7 - Actuarial freedom from thromboembolism.

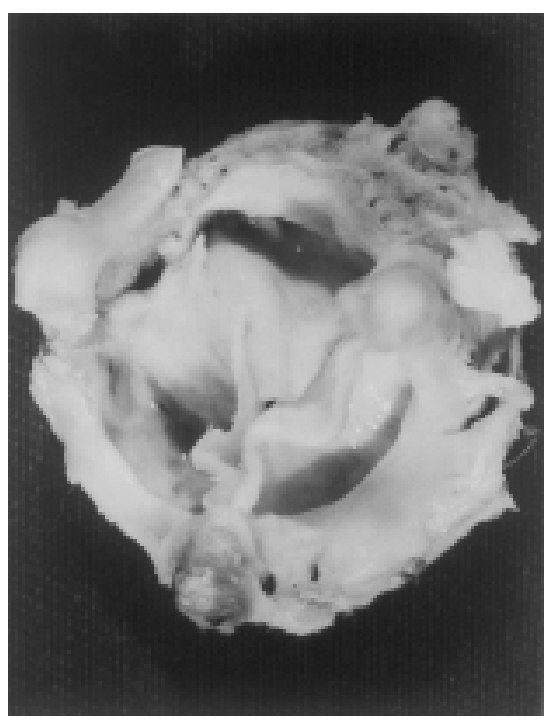

Figure 8 - Dura mater bioprosthesis recovered 25 years after implantation. Note the preservation of the tissue in a great portion of the valve. ing the late postoperative period ( 5 years) and therefore were not related to the sterilization method.

The dura mater bioprosthesis is associated with low thrombogenicity, but structural deterioration constitutes the main reason for reoperation ${ }^{14,15}$. The main complication was tissue tears, and these were observed after 6 years of follow-up. A higher incidence of this complication occurred after 10 to 25 years of follow-up in patients who underwent mitral valve replacement. Rupture did not occur in patients who underwent tricuspid valve replacement, perhaps because of the lower hemodynamic stress associated with right ventricular systole ${ }^{16}$. The occurrence of rupture between 10 and 25 years postoperatively is an observation favorable to the dura mater bioprosthesis and indicative of its durability. The actuarial freedom from rupture at 30 years was $27.0 \% \pm 10.2 \%$.

Dura mater bioprostheses are associated with low rates of calcification. This is probably because they are composed of a homologous tissue, and are dehydrated with $98 \%$ glycerol without chemical interaction with the amino radicals that compose the collagen fibril protein structures. At 30 years, the actuarial freedom from calcification was $78.8 \% \pm 8.6 \%$.

With the Carpentier-Edwards standard porcine bioprosthesis, Jamieson et al. demonstrated that freedom from structural valve deterioration after mitral valve replacement was $21 . \% \pm 3.9 \%$ at 15 years $^{17}$ and $8.5 \% \pm 3.4 \%$ at 18 years ${ }^{18}$. In contrast, freedom from structural dysfunction was $20.9 \% \pm 8.3 \%$ at 30 years in our study, although we must consider the limited number of patients compared with the other series. Whereas our data do not demonstrate overall superiority of the dura mater prosthesis, they do suggest that calcification rates are lower and that rupture occurs later with this bioprosthesis than with others.

Biological prostheses often fail after implantation, and patients usually must undergo reoperation, primarily because of structural valve deterioration. The freedom from reoperation in our series of 70 patients was $18.8 \%$ $\pm 7.5 \%$ at 30 years. Dura mater bioprostheses were associated with a lower incidence of calcification compared with pericardial and porcine prostheses treated with glutaraldehyde (Fig. 8). Rupture occurred more frequently than calcification. However, we must consider that this series only included adult patients, and calcification occurs more frequently in infants.

The learning curve explains the cases of technical failure observed in our study. At that time, surgeons were 
prepared to implant Starr-Edwards prostheses, which do not require attention to the position of the fixation stitches. In the case of bioprostheses, misplaced stitches can interfere with the frame, holding the cusps and causing valvular insufficiency.

Using electron microscopy, Allen et al. ${ }^{19}$ studied 12 dura mater bioprostheses removed in reoperations after 23 to 108 months of implantation. These authors observed evidence of cellular remodeling and concluded that the long durability of these bioprostheses may relate to factors such as the preservation of collagen fibers by glycerol and the viability of fibroblasts and macrophages inside the dura mater tissue. These findings indicate that dura mater bioprostheses are structures actively involved in the process of surface degeneration and remodeling.

At our institution, a protocol study for the selective fixation of dura mater with glutaraldehyde is being developed in order to improve resistance to rupture without compromising cusp pliability. Three patients received these new dura mater bioprostheses 5 years ago and they have experienced a normal evolution up until now.

In conclusion, the dura mater bioprosthesis may offer some advantages over other prostheses including low thrombogenicity, superior durability, and good pliability. However, the dura mater bioprosthesis has 2 operational problems that limit its use-the reliability of the sterilization process and the low availability. Only by solving these problems will we be able to resume the use of dura mater bioprostheses.

\section{RESUMO}

PUIG LB e col. - Bioprótese de dura mater mitral e tricúspide: 30 anos de acompanhamento. Rev. Hosp. Clín. Fac. Med. S. Paulo 58(3): 163-168, 2003.

A bioprótese de dura-mater foi desenvolvida no Hospital das Clínicas da Faculdade de Medicina da Universidade de São Paulo em 1971. Este trabalho apresenta os resultados clínicos com 30 anos de seguimento.

MÉTODOS: Foram estudados 70 pacientes consecutivos com bioprótese mitral ou tricúspide, operados de janeiro de 1971 a agosto de 1972.

RESULTADOS: A mortalidade imediata foi $10 \%$ (7 pacientes). Dois pacientes evoluem bem com a bioprótese de dura-máter, 9 não tem seguimento atualizado, 33 apresentaram disfunção da bioprotese e foram reoperados e 19 faleceram durante a evolução tardia. A curva atuarial de sobrevida foi de $49,2 \pm 8,6 \%$, livre de rotura, $27,0 \pm$ $10,2 \%$, livre de calcificação, $78,8 \pm 8,6 \%$ e livre de reoperação, $18,8 \% \pm 7,5 \%$.

CONCLUSÕES: A bioprótese de dura-mater teve mais importante papel no tratamento de pacientes com lesão das valvas mitral e tricúspide. A baixa taxa de tromboembolismo e o longo período de seguimento sem disfunção valvar em vários pacientes são importantes características desta bioprótese.

DESCRITORES: Dura-mater. Bioprótese valvar mitral e tricúspide. Glicerina. Cirurgia valvar. 


\section{REFERENCES}

1. PUIG LB, VERGINELli G, BELlOtTI G, KAWABE L et al. Homologous dura-mater cardiac valve. Preliminary study of 30 cases. J Thorac Cardiovasc Surg 1972;64:154-160.

2. PUIG LB, VERGINELli G, KAWABE L et al. - Valva cardíaca de dura-mater homóloga. Rev Hosp Clín Fac Med São Paulo 1974;29:85-89.

3. STOLF NAG, DALLAN LA, PUIG LB et al. - Clinical results of valve replacement by the Starr-Edwards prosthesis. Artif Organs 1980;4:24-26.

4. EDMUNDS LH Jr, CHAIRMAN, CLARK RE et al. - Guidelines for reporting morbidity and mortality after cardiac valvular operations. Ann Thorac Surg 1996; 62:932-935.

5. PIGOSSI N, RAIA A, LEX A et al. - Estudo experimental e clínico sobre o emprego como implante, da dura-mater homogenea conservada em glicerina a temperatura ambiente. Rev Assoc Med Bras 1971; 17:263.

6. HIGHISON GL, ALLEN DJ, DiDIO LJA et al. - Ultrastructural morphology of dura-mater aortic allografts after 44-73 months of implantation. J Submicros Cytol 1980; 12:165-187.

7. ZERBINI EJ, PUIG LB - The dura-mater allograft valve. In: IONESCU MI - Tissue Heart Valves. London, Butterworth, 1979. v.7, p.253-301.

8. ZERBINI EJ, PUIG LB - Experience with dura-mater allograft. In: SEBENING F - Bioprosthetic Cardiac Valves. Munchen, Deutsches Herzzentrun, 1979. v.3, p.179-90.

9. OYER PE, STINSON EB - Biologic valves. In: GLEN WWL et al. - Thoracic and Cardiovascular Surgery. Connecticut, Appleton-entury Crafts, 1983. v.95, p.1362-1369.

10. ZERBINI EJ, PUIG LB, VERGINELLI G - Dura-mater valve. In: YANGKAI WE, PETERS RM - International Practice in Cardiac Surgery. Beijing, Science Press Book, 1985. v.83, p.966-977.
11. KIRKLIN JW \& BARRATT-BOYES BG - Aortic Valve Disease. Cardiac Surgery. $2^{\text {nd }}$ ed. Londo, Churchill, 1983. v.12, p.491571.

12. BURAKORVSKY BI, BOKER YA - Cirurgia Cardiovascular. Moscou, Medicina, 1989. p. 424.

13. HARASAKI H, KIRALY RJ, JACOBS GB et al. - Bovine aortic and human dura mater valves: a comparative study in artificial hearts in calves. J Thorac Cardiovasc Surg 1980;79:125137.

14. PUIG LB, VERGINELLI G, IRYIA K et al. - Homologous duramater cardiac valves. Study of 533 surgical cases. J Thorac Cardiovasc Surg 1975; 69:722-728.

15. PUIG LB - Bioprótese Cardíaca de Dura-Mater. Arq Bras Cardiol 1997; 69(3): 153-154.

16. PUIG LB, BRANDÃO CMA, POMERANTZEFF PMA et al. Tricuspid dura mater bioprostheses: more than 20-year followup of 3 patients. Ann Thorac Surg 2001; 72:615-617.

17. JAMIESON WR, MUNRO AI, MIYAGISHIMA RT et al. Carpentier-Edwards standard porcine bioprosthesis: clinical perfomance to seventeen years. Ann Thorac Surg 1995; 60:999-1007.

18. JAMIESON WR, BURR LH, MUNRO AI et al. - Carpentier-Edwards standard porcine bioprosthesis: a 21-year experience. Ann Thorac Surg 1998; 66:S40-3.

19. ALLEN DJ, HIGHISON GJ, DIDIO LJA et al. - Evidence of remodeling in dura mater cardiac valves. J Thorac Cardiovasc Surg 1982; 84:267-81. 